$$
\text { Gyula Pulay, József Simon }
$$

\title{
The Resilient Adaptation of Budgets to Small and Shock-like Changes
}

\section{Summary}

After the 2008-2009 global financial crisis it became even more important that the countries observed the budgetary rules, while also being flexible in adapting to the changes occurring during the year. This is called fiscal resilience. This article presents the possible means to create fiscal resilience. Taking into consideration the recommendations of international organisations, it emphasises that the measures ensuring the flexibility of the budget shall be realised in a transparent manner. Based on the relevant European Union legislation and the Hungarian regulation and practice the authors argue that the content of resilience changes in the event of external shocks. In that case the resilience of the budget shall be subordinated to the recovery of the entirety of the economy, i.e. its resilience. The primary goal is not to maintain the deficit target but to avoid a severe and permanent economic downturn and then to encourage the recovery.

Journal of Economic Literature (JEL) codes: H30, H61, H71, H72

Keywords: resilience, flexibility, central budget, reserves

Dr Gyula Pulay PhD, Supervisory Manager, associate professor, State Audit Office of Hungary, University of Miskolc (szvpulay@uni-miskolc.hu), Dr JózsEF Simon $\mathrm{PhD}$, Audit Manager, associate professor, State Audit Office of Hungary, Eötvös József College (simon.jozsef@ejf.hu). 
Gyula Pulay, József Simon: The Resilient Adaptation of Budgets to Small...

\section{INTRODUCTION}

The global financial crisis that erupted in 2008 directed the attention to the fact that not all countries were prepared for managing the economic shocks, and for this reason the sudden economic downturn led to disruption in the balance of their budgets and drastic increase in their government debt. All these put increasing the flexible reaction ability of the budget in the forefront, in other words, increasing the resilience of the budget.

The Hungarian economy suffered tremendous losses due to the global crisis, one of the very reasons behind which was that due to the severe indebtedness of the state the central budget was unable to react in a flexible manner to the effects of the world economy shock. The resilience of the budget is crucial for the other economic operators as well, since this softens the negative impacts of change in the external environment they suffer. The current epidemic is a good example for this, during which the budget helps the survival and the recovery of suffering enterprises by reducing the taxes and providing direct aids.

This study examines the flexibility of the implementation of the budget according to a resilience-based approach. In the general sense resilience means the ability of flexible resistance, i.e. the ability of a system to successfully adapt to powerful, repeated or even shock-like external effects. The flexibility of the implementation of the budget - as deduced from the conceptual framework established by international organisations - expresses the size of the room for manoeuvre of the entities responsible for the implementation of a country (in Hungary, the Government, the management bodies of each chapter of the budget, as well as the budgetary authorities and the managers of the appropriations and funds) have with regard to the development of the budget revenues different from the plan, and to react reasonably to the changes affecting the expenses, without going beyond the statutory frameworks. Resilience is designated to manage the country risks in case of external shocks.

\section{THE RESILIENCE OF THE IMPLEMENTATION OF THE BUDGET - INTERNATIONAL APPROACH}

The international organisations - especially the Organisation for Economic Cooperation and Development (OECD) and the International Monetary Fund (IMF) - also examine the topic of fiscal resilience. These organisations typically specify and interpret principles related to budget management. The concept of the flexibility of the implementation of the budget can be deduced from these principles as well.

The recommendations of the OECD Council on good budgetary governance (OECD, 2015) formulate those principles through the realisation of which the countries are able to prepare and implement more transparent, more effective and more reliable budgets. The following principles of the recommendation are related to the resilience of the implementation of the budget: 
"7. Actively plan, manage and monitor the execution of the budget, through:

a) the full and faithful implementation by public bodies of the budget allocations, once authorised by parliament, with oversight throughout the year by the Central Budget Authority and line ministries as appropriate;

d) allowing some limited flexibility, within the scope of parliamentary authorisations, for ministries and agencies to reallocate funds throughout the year in the interests of effective management and value-for-money, consistent with the broad purpose of the allocation;

e) streamlining of very detailed line items, or devolved authorisation for managing reallocations among line items (virement), in the interests of facilitating such flexibility; noting that more significant reallocations, e.g. involving large sums or new purposes, should require new parliamentary authorisation;

f) the preparation and scrutiny of budget execution reports, including in-year and audited year-end reports, which are fundamental to accountability and which, if well-planned and -designed, can yield useful messages on performance and value-formoney to inform future budget allocations.

8. Ensure that performance, evaluation and value for money are integral to the budget process, in particular through: a) helping parliament and citizens to understand not just what is being spent, but what is being bought on behalf of citizens - i.e. what public services are actually being delivered, to what standards of quality and with what levels of efficiency;

b) routinely presenting performance information in a way which informs, and provides useful context for, the financial allocations in the budget report; noting that such information should clarify, and not obscure or impede, accountability and oversight; d) evaluating and reviewing expenditure programmes (including associated staffing resources as well as tax expenditures) in a manner that is objective, routine and regular, to inform resource allocation and re-prioritisation both within line ministries and across Government as a whole;

e) ensuring the availability of high-quality (i.e. relevant, consistent, comprehensive and comparable) performance and evaluation information to facilitate an evidencebased review;

f) conducting routine and open ex ante evaluations of all substantive new policy proposals to assess coherence with national priorities, clarity of objectives, and anticipated costs and benefits;

9. Identify, assess and manage prudently longer-term sustainability and other fiscal risks, through:

a) applying mechanisms to promote the resilience of budgetary plans and to mitigate the potential impact of fiscal risks, and thereby promoting a stable development of public finances;

b) clearly identifying, classifying by type, explaining and, as far as possible, quantifying fiscal risks, including contingent liabilities, so as to inform consideration and debate about the appropriate fiscal policy course adopted in the budget; 


\section{Gyula Pulay, József Simon: The Resilient Adaptation of Budgets to Small...}

c) making explicit the mechanisms for managing these risks and reporting in the context of the annual budget;

d) publishing a report on long-term sustainability of the public finances, regularly enough to make an effective contribution to public and political discussion on this subject, with the presentation and consideration of its policy messages - both nearterm and longer-term - in the budgetary context."

It follows from the principles cited above that with regard to the flexibility of the budget's implementation it is crucial that the Government monitors the implementation of the budget continuously and corrects the possible differences through the means of budgeting created for this purpose. It is important that the toolkit is prepared in advance; and the appropriate combination of the toolkit can be used in case of both favourable and unfavourable changes.

It can be deduced from the OECD principles that the flexibility of the implementation of the budget is a protective force in the event the economic and business conditions change unexpectedly. The goal is to ensure that the organisations responsible for the implementation of the central budget are able to adapt adaptively, while not going beyond the original budgetary deficit target and avoiding the increase of the governmental debt in excess of the planned amount.

The OECD recommendation uses the word "resilience" in two aspects. Firstly it specifies resilience as a criterion for stable fiscal policy. Secondly, it recommends the use of planning mechanisms which build those elements in the budget which are necessary to manage the risks arising in course of the implementation of the budget. Later, in consideration of the Hungarian regulation we will present the possible elements.

The IMF understands the concept of fiscal flexibility as the ability to manage risks. The code published by IMF in 2014 (Fiscal Transparency Code) orders the principles of transparency of the budget in groups around three pillars. These pillars and the principles belonging to those are presented in Figure 1.

One of the tools of resilience is risk management within the pillar for fiscal risk analysis and management. In the framework of this the IMF deems it is necessary to use fiscal instruments which are suitable for monitoring, discovering and managing the occurrence of risks. By this the IMF emphasises the justification and the importance of the flexibility of the implementation of the budget.

The Fiscal Transparency Handbook published by the IMF in 2018 - which was intended to facilitate the implementation of the code - contains a flexibility definition which has a unique aspect. According to the interpretation of the Fiscal Transparency Handbook, flexibility in fiscal policy is important mostly with respect to the management of economic shocks. For this reason, in case of economic growth and stability this is ensure room for manoeuvring in the budget and prepare for the possible, less controllable economic shocks. According to the recommendation of the IMF, the application of such unambiguously defined fiscal rules is justified which ensure flexibility, in addition to the balance of the budget.

The OECD and rather the IMF recommendations reason why the two cases of resilience should be separated. In the first case the organisations responsible for the 
Civic Review · Vol. 16, Special Issue, 2020

Figure 1: The three-pillar system of the IMF' transparency approach
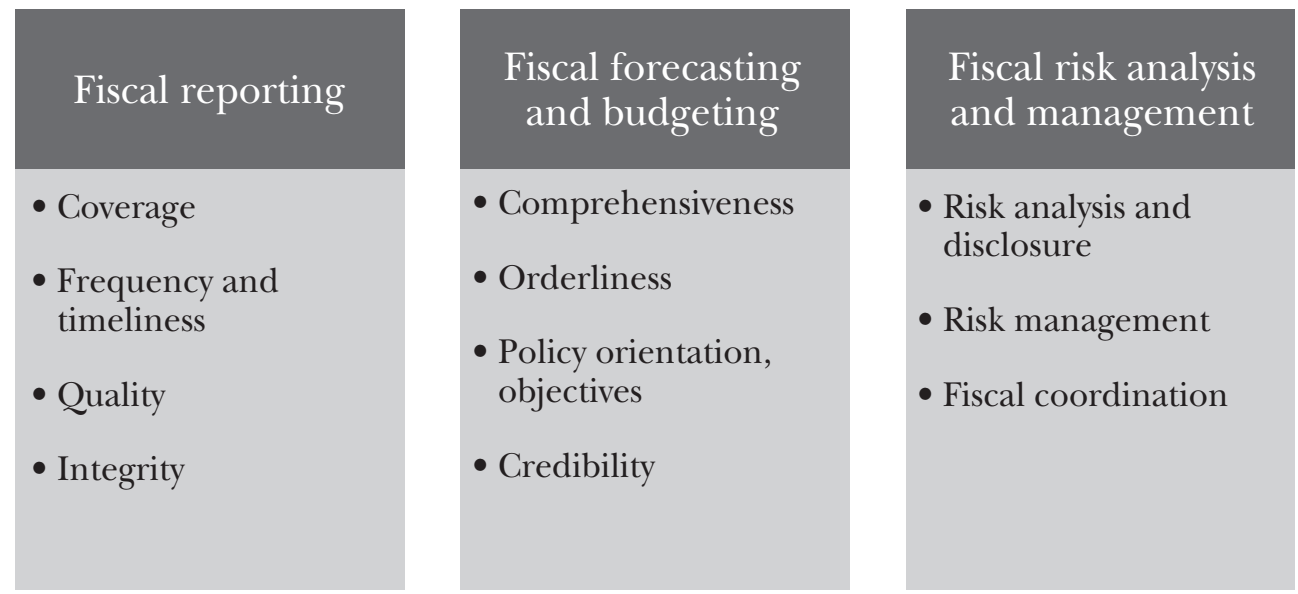

Source: Edited by SAO (Pulay et al., 2019, p. 10), based on IMF, 2014, pp. 1-4

implementation of the budget have to adapt to the unexpected, significant, but not shock-like changes of the environment, while keeping the fulfilment of the deficit target in mind. In the other case, the external environments suffers a shock, and the main task is to soften this shock and facilitate recovery after it.

\section{What IS THE CONTENT OF THE RESILIENCE OF THE BUDGET IN CASE OF NON-SHOCK-LIKE EXTERNAL CHANGE?}

Taking into consideration the international literature presented above, the flexibility of the implementation of the budget is understood as resilience by this article as well. In a general sense resilience means the quality of being able to return quickly to a previous good condition after problems. Resilience is often illustrated by the comparison of an egg and a rubber ball. The rigid and hard shell of an egg is able to withstand small pressure, however, in case of great pressure, the egg will break and will never regain its shape. In contrast, a rubber ball inflated by air will be indented if subjected even to small pressure, however, once the pressure ceases, it will bounce back to its original shape. Naturally, certain force will completely destroy the rubber ball as well. Thus, the resistance of an egg is rigid, while the rubber ball's is flexible, consequently, the resilience of an egg is minimal, while a rubber ball has high resilience.

We compare the resilience of the budget not to the resilience of ball but a bicycle wheel. In case of a bicycle wheel, the stable structure is ensured by the metal rim and the stokes, while the rubber tire ensures flexibility, which on the one hand is springiness, and on the other hand is resilience. Springiness, which softens the constant vibration due to the small bumps in the road, and resilience, which protects the rigid frame from collapsing in case of bigger bumps. In case of the implementation of the 
budget, the flexibility helping the daily implementation and the resilience enabling flexible adapting to the larger changes in the environment are both necessary. The better flexibility of the budget may be ensured if all organisational levels responsible for the implementation of the budget (Government, the management bodies of each chapter, budgetary authorities) have tools promoting flexibility, and if such tools protect the budget as a flexible layer from constant shakes and larger changes. This connection is illustrated by Figure 2.

Figure 2: The layers ensuring the resilience of the implementation of the budget

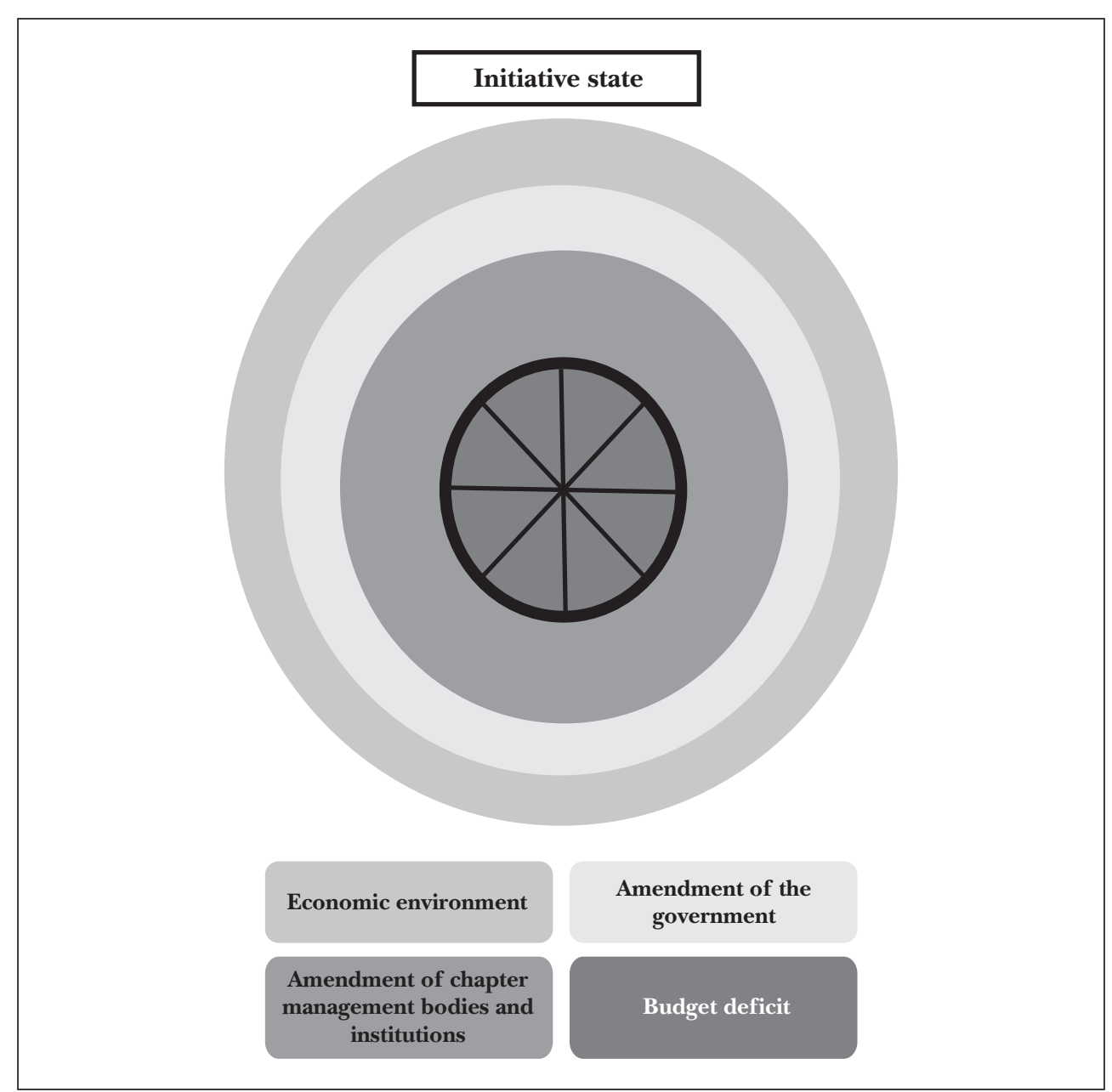

Source: Edited by the authors

Figure 3 shows how we interpret the resilience of the budget and therefore consider it feasible. The key point of this is that in case of a bigger shock the levels responsible for the implementation of the budget deploy their own tools, empty their 
reserves if necessary, however, the solidity of the internal core remains, i.e. the fiscal rules specified by law and the most important fiscal objectives are fulfilled.

Figure 3: The resilience of the budget in case of shocks

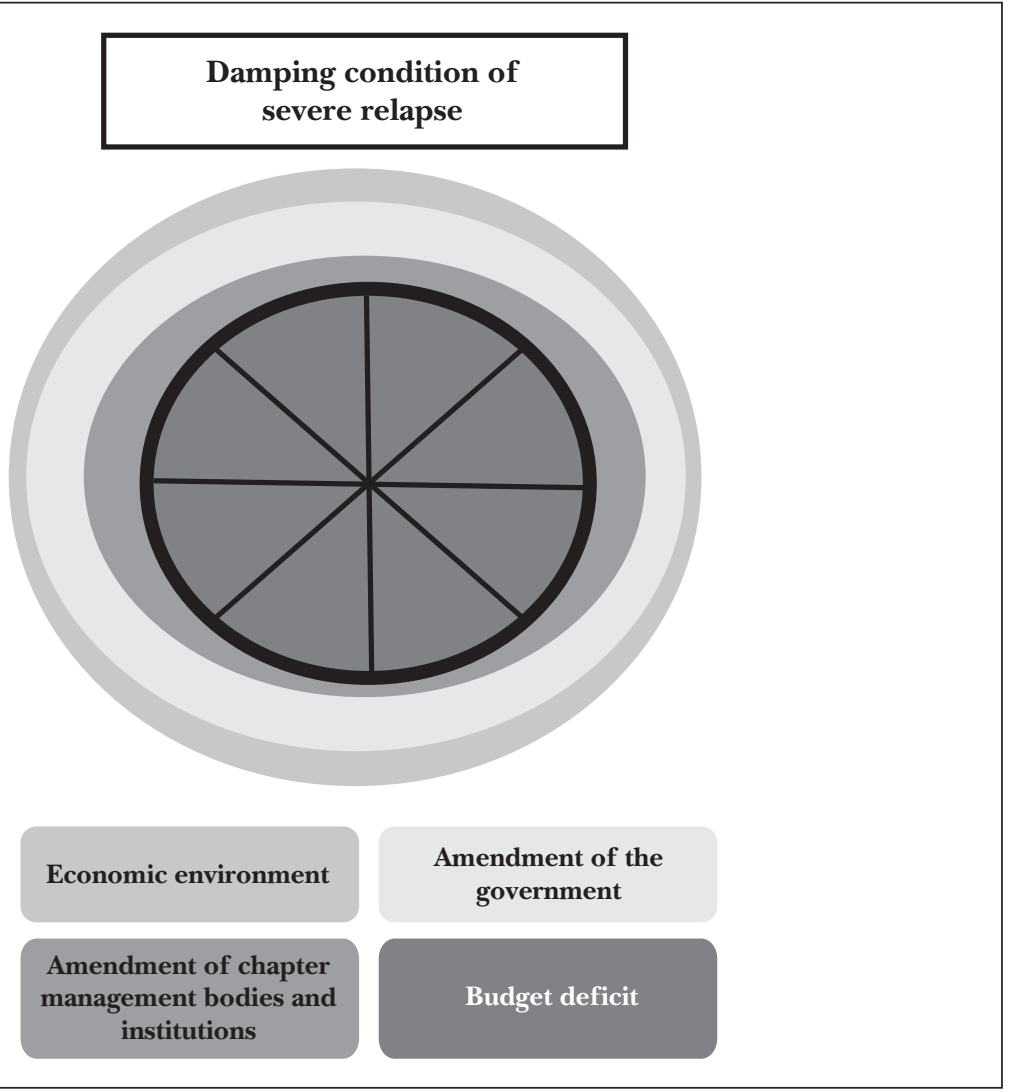

Source: Edited by the authors

From the perspective of the implementation of the budget, flexibility is made necessary essentially by two factors. On the one hand, less or more revenue than the planned amount may be realised during the year. On the other hand, in course of the implementation of the budget, the fulfilment of the expense appropriations may change compared to the original appropriations (e.g. an investment progresses slower, or more people become eligible for an aid). The fulfilment of the revenue and expense appropriations may differ from the original appropriations for multiple reasons, accordingly, over- or underperformance may occur during or at the end of the fiscal year. The reasons for the difference include changes in the content or extent of the public duty, changes in the scope of users, the appearance of a new public duty, changes in the economic circumstances (e.g. realising higher tax revenues than planned as a result of economic growth higher than planned), or the occurrence of a natural disaster. 


\section{Gyula Pulay, József Simon: The Resilient Adaptation of Budgets to Small...}

The content of the flexibility of the central budget is fundamentally influenced by the balance of the over- and underperformance of the appropriations. If the balance is better than planned, then the flexibility can be measured in the room for manoeuvring the entity responsible for the implementation of the budget - i.e. the Government - has for paying the extra costs in order to facilitate or expedite the realisation of the economic policy and other objectives. If the balance is worse than planned, then the flexibility of the budget means that there are tools available with the help of which the deficit target can be achieved without detriment to the fulfilment of public duties.

Why is the resilience of the budget important? From the perspective of exclusively the budget sector, resilience has two significant consequences. The first is that despite environmental changes, the main objectives of the budget are fulfilled. The second is that the budgetary authorities are able to fulfil their public duties in a slightly changed environment as well, and their appropriations designated for this purpose will be reduced during the year only if absolutely necessary. At the same time, the resilience of the budget increases predictability, and therefore in the broader sense, it provides greater security for the other operators of the economy. For example, they do not have to be afraid that the tax rates will be increased during the year, or that the budgetary authorities will not pay their invoices since the funds for those are blocked. Compliance with the government debt is a factor increasing stability of the enterprises, since in this way the state does not create additional demand for money, i.e. it does not force the enterprises and the households out of the money markets. Consequently, the resilience of the budget is a not a technical issue of fiscal nature but it has serious economic policy relevance.

\section{THE RESILIENGE OF THE IMPLEMENTATION \\ OF THE BUDGET IN PRACTICE}

The flexibility of the implementation of the budget can be analysed at the different elements of the budget process:

- In case of regulation the question is whether the statutory and decree regulations related to the implementation of the budget established the flexible protection system ensuring the resilience of the implementation of the budget, and whether the elements of these align with one another harmoniously.

- In the analysis of the role of planning, two questions should be answered. The first is whether the planning is well-founded, i.e. whether it contains mistakes (e.g. the unrealistic over-planning of certain revenue appropriations or the under-planning of expense needs) which will severe problems in course of the implementation. The second question to be answered is weather enough reserves had been planed for managing the foreseeable budget risks.

- With respect to the monitoring of the implementation the main question is whether a system had been established which is able to track the deviations form the plan up-to-date, moreover, the expected deviations. 
Civic Review · Vol. 16, Special Issue, 2020

- The points of intervention can also be analysed, i.e. whether those who are responsible for the decision have proper competence and information for the making the necessary decision in due time.

- Does the budgetary reporting system ensure the transparency and accountability of the flexible (i.e. different from the appropriation specified in the budget act) use of the budgetary appropriations.

In consideration of the above it is important to emphasise that the budget flexibility requirement should be taken into account as a crucial aspect as early as during the planning. The use of budget tools supporting flexibility assumes the existence and operation of a budget planning system of appropriate quality, by assessing the risks involved in the management and forecasting the fulfilment of each appropriation and the circumstances defining it (Pulay, 2013).

\section{THE FLEXIBILITY OF THE IMPLEMENTATION OF THE HUNGARIAN GENTRAL BUDGET}

The basis of the interpretation opportunity of resilience is Article 37 (1) of the Fundamental Law of Hungary, which stipulates that "the Government shall be obliged to implement the central budget in a lawful and expedient manner, with efficient management of public funds and by ensuring transparency". Considering this provision of the Fundamental Law of Hungary, in addition to the flexible reaction ability, the transparency of the fiscal processes shall be ensured as well. This means that - on the one hand - in the interest of resilience it has to be guaranteed that the bodies responsible for the implementation of the budget can deviate from the appropriations specified in the budget act to the extent justified and permitted by law. On the other hand, these bodied should make the reasons for the deviations transparent not only for the National Assembly but for the taxpayers as well.

Keeping the implementation of the budget within the legal frameworks expresses three things:

- the budget rules - i.e. the rules applicable to the balance and the government debt as well - are observed,

- the implementation bodies do not go beyond their scopes of competence, and

- the adoption of the measure does not require the separate decision of the National Assembly. (This latter is a necessary condition because if the decision of the National Assembly, i.e. the amendment of the original budget is required, then it is already the flexibility of not only the implementation but the entire budgeting process.)

At the same time, the flexibility of the implementation of the budget affects the room for manoeuvring of the implementation levels. The room for manoeuvring of the government, management body and institutional implementation levels can be extended only to the detriment of the other levels (or any one of the levels). From this perspective, the room for manoeuvring of the Government can be considered the primary one, since according to the Fundamental Law of Hungary, the general responsibility of the implementation is borne by the Government. According to the 
Gyula Pulay, József Simon: The Resilient Adaptation of Budgets to Small...

Hungarian regulations, the room for manoeuvring of budgetary authorities and chapter managing bodies is rather broad. This may represent a limitation for the Government, since it restricts the opportunities of the Government to react reasonably to unexpected events while keeping in mind the effectiveness of the use of public funds.

The room for manoeuvring of the implementation of the budget of any given year may be expanded to the detriment of the budgeting room for manoeuvring of the next year (years). This is favourable, moreover, essential from the perspective of the year concerned. At the same time, if the sum of the residual amounts to be carried forward to the year following the fiscal year and the amount of the obligations reaches a certain amount, then this narrows the budgeting room for manoeuvring of the year concerned significantly (including the room for manoeuvring of not only the bodies responsible for the implementation but that of the National Assembly, which enacted the budget act).

The ratio of budget appropriation amendments realised in course of the implementation of the Hungarian central budget between 2017 and 2019 to the original appropriations is summarised by Table 1. It can be established that the appropriations of the central budget changed significantly in all three years as a result of the decisions of the three levels of implementation (Government, budget chapter management bodies, the budgetary authorities themselves), which decisions amended the appropriations. At the same time, the two most important objectives - i.e. maintaining the deficit calculate according to the EU methodology under $3.0 \%$ and the reduction of the government debt indicator - were fulfilled in all three years.

Table 1: Budget appropriation amendments expressed in the percentage of the expense appropriations of the central budget (2017-2019)

\begin{tabular}{l|r|r|r}
\hline Description & $\mathbf{2 0 1 7}$ & $\mathbf{2 0 1 8}$ & $\mathbf{2 0 1 9}$ \\
\hline Legislative amendment & 2.4 & 0.0 & 0.0 \\
\hline Amendment within the competence of the Government & 1.3 & 2.2 & 1.9 \\
\hline $\begin{array}{l}\text { Amendment within the competence of the chapter } \\
\text { management bodies }\end{array}$ & 11.5 & 8.0 & 5.3 \\
\hline Amendment within the competence of budget institutions & 11.7 & 12.0 & 10.4 \\
\hline Amended budget appropriation & 126.9 & 122.2 & 117.6 \\
\hline
\end{tabular}

Source: 2017, 2018 and 2019 acts on the final balance and the reasoning thereof

The Hungarian laws specify numerous fiscal instruments which influence the flexibility of the implementation of the budget. The instruments created by the laws and ensuring flexibility include:

- the creation and use of reserves,

- amendment and transfer of appropriations,

- the use of residual appropriations,

- the use of appropriations which can exceeded unconditionally or subject to authorisation,

- blocking or deleting of appropriations. 
Civic Review · Vol. 16, Special Issue, 2020

The common characteristic of these instruments is that by using them in course of the implementation of the budget the unexpected effects, as well as the consequences of the changes occurred in the conditions of the implementation of the budget become manageable. However, in course of his it is an important requirement that the measures executed in the interest of flexibility should not reduce, or should reduce only to the absolutely necessary extent the effectiveness of the implementation of the budget, for example, they should not led to the failure of public duties, wasteful overspending, or the liquidity issues of the suppliers of budgetary authorities.

The use of budgetary instruments supporting resilience can be considered regular in course of the implementation of the budget. In the following two of the instruments will be highlighted, the reason behind which is that these are the ones that determine the rate of the resilience.

\section{The creation and utilization of reserves}

In recent years a multiple-element system of provisioning has developed in the Hungarian central budget, which increased the resilience of the implementation of the budget significantly (Domokos, 2019).

In recent years the budget act has always included reserve appropriations. These appropriations were used in full during the years between 2017 and 2019.

The role of reserves are different in case of unplanned budget expenses and in case of less than planned budget revenues. Namely, the fulfilment of unexpected expense needs is accompanied by the use of reserves, and as a result, the composition of the expense side of the budget will change, but the expense total will not. In case of unexpected loss of revenue however, in the amount of the loss or revenue the appropriation of the revenue concerned and the reserve as appropriation - and simultaneously the revenue and the expense totals as well - will decrease. Thus, if the revenues develop as planned or in excess thereof, then the reserves can be used for covering the unplanned expenses. In this case however, it shall be taken into consideration than the majority of the extra expense appropriations permitted to the debit of the reserves released on the fourth quarter - in the absence of preliminary preparations - cannot be used until the end of the year. Consequently, a significant part thereof will burden not the year concerned but the next fiscal year as actual expense. In order to avoid this and not well-thought-out uses it is advisable to specify in advance those expense appropriations which are reasonable to be increased o case the reserves are released, since the effective use of the appropriations within the year concerned can be ensured in this way. This a typical case for when the constitutional principle of the effective use of public funds is taken into consideration by the resilience of the implementation of the budget.

\section{Amendment and transfer of appropriations}

Appropriation amendment is the increase or decrease of the revenue appropriation or the expense appropriation. Appropriation transfer is an amendment executed so 
Gyula Pulay, József Simon: The Resilient Adaptation of Budgets to Small...

that the total of the aggregated expense appropriations of the budget of the entity executing the transfer remain unchanged, while the expense appropriations are decreased and increased simultaneously.

Appropriation transfers affect the flexibility of the central budget only if any reserve-like appropriation is concerned by the transfer, as well as if any extra revenue or expense savings is transferred within the budget. The flexibility of the central budget is improved by the increase in the value of the reserves, while it is decreased by the use of the reserves. The use of the reserves affect the flexibility of the central budget adversely because the room for manoeuvring of the Government becomes narrower to the same extent with regard to effects that may occur.

The possibility of transfer between the appropriations and between the years increases the flexibility of the implementation of the budget significantly. This is illustrated by Figure 4 .

Figure 4: The effect of the possibility of transfer between the budget appropriations and the years on the flexibility of the budget

\begin{tabular}{|c|c|c|c|c|c|c|}
\hline \multirow{2}{*}{$\begin{array}{l}\text { Expense } \\
\text { appro- } \\
\text { priations }\end{array}$} & \multicolumn{2}{|c|}{ Plan } & \multicolumn{2}{|c|}{ Actual without transfer } & \multicolumn{2}{|c|}{ Actual with transfer } \\
\hline & 1st year & 2nd year & 1st year & 2nd year & 1st year & 2nd year \\
\hline \multicolumn{7}{|l|}{$\mathbf{A}$} \\
\hline \multicolumn{7}{|l|}{ B } \\
\hline \multicolumn{7}{|l|}{ C } \\
\hline D & & $1 / 1 / 12$ & & 121212 & 12 & 717 \\
\hline \multicolumn{7}{|l|}{ Total } \\
\hline & & & & & & 11 \\
\hline
\end{tabular}

Source: Edited by SAO (Pulay et al., 2019, p. 30)

The figure shows that the implementation of the public duties and the related appropriations included in the budget may take place in different way.

In case of appropriation "A", the obligation was undertaken, however, the actual financial use for a part of the appropriation will take place in the next year. As a result, the in the first year the expense will be lower that the appropriation, while in the future year the next year's expense will be increased by the value transferred.

Appropriation "B" developed as planned. In case of this appropriation the use did not affect the flexibility of the budget.

Appropriation "C" was not used in full, however, as a result the program would have to be continued in the next year, although it was not planned. 
Civic Review · Vol. 16, Special Issue, 2020

In case of appropriation " $\mathrm{D}$ ", the plan is that the use of the appropriation will start only in the 2nd year, however, the launch of the project concerned became necessary before due to some circumstances. Such circumstances may be the faster than planned progress of the preparatory tasks of the investment concerned.

If there is no possibility to transfer funds within the budget, then savings will be accumulated in the first year, however, extra expenses can be expected in the second year. The imbalances occurring as a result can be balanced through transfers. The way to do this is transferring the savings of appropriation " $\mathrm{C}$ " to appropriation " $\mathrm{D}$ ", while the savings of appropriation " $\mathrm{A}$ " are transferred in order to fulfil the next year's duties.

\section{FLEXIBILITY AND TRANSPARENCY}

Due to the use of the budgetary instruments supporting flexibility which were presented in course of the implementation of the budget, it is especially important to present that the appropriations that changed in course of the implementation of the budget compared to the budget act passed by the National Assembly, as well as the reasons behind the changes. Based on the presentation of these data and correlations can the National Assembly assess whether the Government had fulfilled the tasks set out properly, and the members of the society may get information about the processes of budgetary management and the key events of the implementation. For all these reasons, ensuring the transparency of the budget is appreciated more and more on the international level. All these show well that the transparency of budget processes is considered as a priority by international organisation as well.

The OECD published its summary on the means increasing the transparency of the budget in 2017. According to the document, the realisation of the budget's transparency has numerous advantages, including accountability, integrity, as well as the strengthening of the citizens' trust and the improvement of the quality of the budget. The OECD summary study formulates the following aspects - among others - as recommendations:

- "Fiscal reports should provide a comprehensive, relevant, timely, and reliable overview of the government's financial position and performance.

- allow for early identification of budgetary overruns/underspends and other risks

- to the extent possible, provide an indicative quantification or measure of fiscal risks

- use internationally-comparable indicators of long-term sustainability."

In the dimension of publicity the most important element is that budget data should be accessible to the citizens. In the framework of this it is a fundamental condition that there are documents available which contain the developments of the budget processes and the related detailed data in a comprehensible manner.

The third pillar of the code published by the IMF in 2014 includes the principle of risk analysis and disclosure. According to this principle, once identified, the risks occurring in course of the implementation of the budget, as well as the method of 
Gyula Pulay, Jozsef Simon: The Resilient Adaptation of Budgets to Small...

managing these risks should be presented in the budget report on the fiscal year concerned.

The IMF published its handbook on budget transparency in 2018, which explains the principles of the code published in 2014 and the practices presented therein, as well as it provides detailed guidance for the implementation of these.

\section{CHANGES IN THE CONTENT OF FISCAL RESILIENGE IN CASE OF SHOCK-LIKE CHANGES}

In the previous chapter we elaborated that the resilience of the budget means better predictability and stability for the economic operators, since the organisations responsible for the implementation of the budget are able to react to smaller environmental changes in a flexible manner, i.e. there is no need for mid-year tax increased which shake up the economy, or restrictive measures which cause the failure of tenders and delays in the payment of contracts. However, the 2008-2009 global financial crisis, or the current epidemic caused shock-like hit of such magnitude that "wounded" part of the economic operators or made their situations impossible. As a result of the severe economic downturn, the revenues of the budget may decrease drastically as well, a direct consequence of which is budget deficit, and through that an increase in the government debt. In this difficult situation the flexibility of the budget does however not mean that the budget deficit is decreased to the planned amount by freezing the reserves and through other instruments mentioned above. If a country is compelled to do so - as was Hungary in 2009 - then this is a sign of inflexibility, i.e. a sign that the budget is unable to undertake supplementary debts. This however leads to the further loss of purchasing power, and consequently to even more severe economic downturn. In this case fiscal policy shall serve the resilience of the entirety of the national economy, i.e. softening the hit of the shock, and once the reason for the shock is eliminated, restarting economic growth again. Naturally, in such case one should not forget about the importance of fiscal resilience in the narrower sense, i.e. another measure of budget flexibility is the time when the budget deficit and the government debt return to a sustainable course after a temporary increase.

Ensuring the resilience of a national economy that had suffered a shock requires that the loss of purchasing power is contained by the state, as well as that the state protects the economic operators from collapsing through targeted aids and helps their recovery. All interventions are accompanied by increase in the budget expenses, meaning that the interventions increase the budget deficit and the government debt even further. Figure 5 provides a good illustration for the situation that occurred in the then-euro area and in the V4 countries as a result of the 2008-2009 global crisis.

The figure is a good illustration of the basic tendency that the budget deficit increased in most countries in 2008 and 2009, and it was typically higher than the budget deficit of 2007 by 4 to 8 percentage points. However, in two countries - in Ireland and Spain - the increase of the deficit exceeded 10 percentage points, while in another two countries - in Malta and Hungary - the deficit of the budget increased only mini- 
Civic Review · Vol. 16, Special Issue, 2020

Figure 5: Changes in the budget deficit-to-GDP ratio in percentage points (\%) in the member states of the euro area and in the V4 countries (2007-2010)

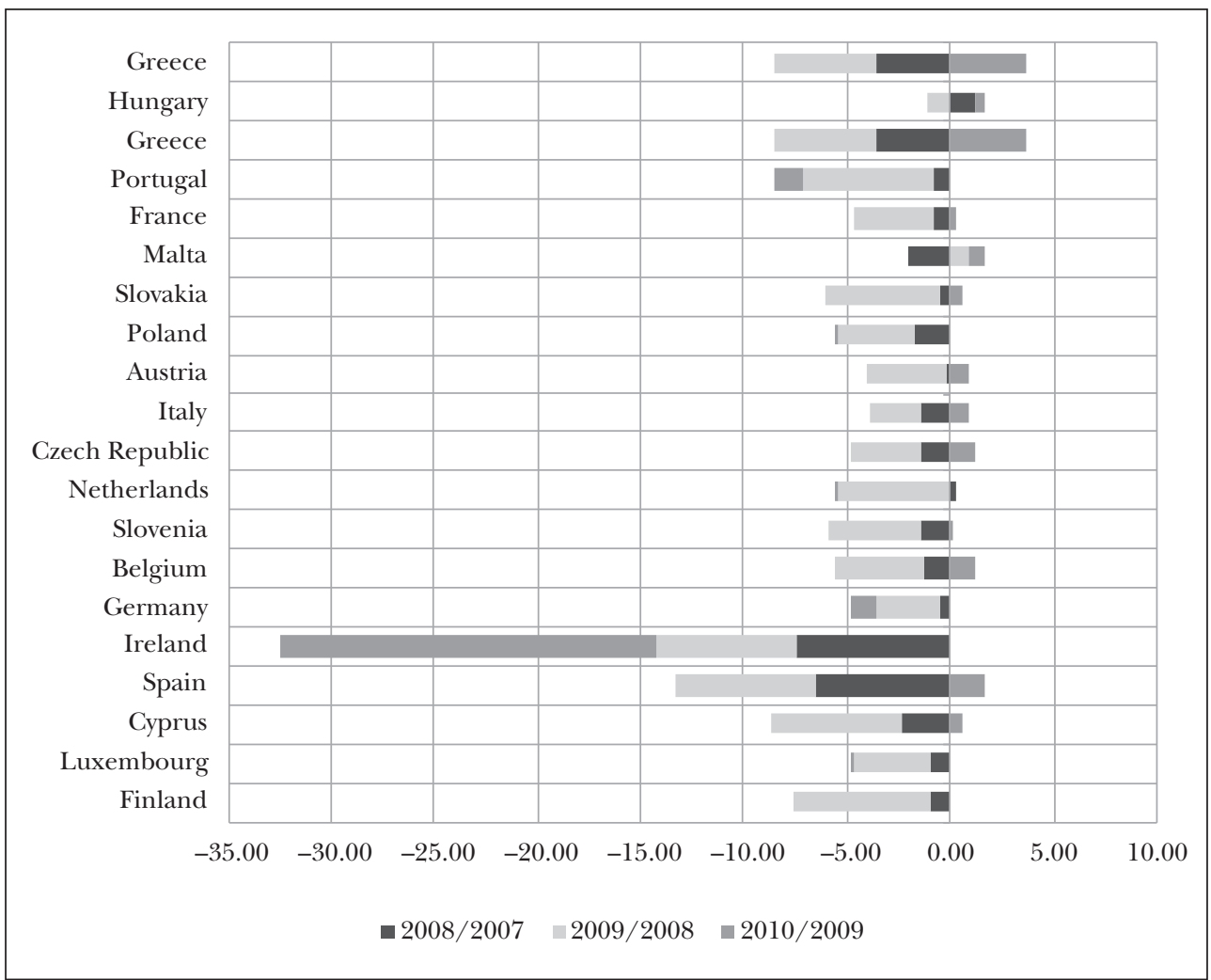

Source: Eurostat, 2020

mally compared to 2017. Figure 6 includes the countries in ascending order based on their 2007 budget deficits. This illustration highlights the correlation according to which during the two years of the crisis those countries were the most able to mitigate the negative effects of the crisis through increasing the budget expenses which had positive or near-balanced budget balances before the crisis (Finland, Cyprus, Spain). Meanwhile, the budget deficit of the countries which increased the budget deficit the least between 2007 and 2009 was relatively high in 2017 already: 2.1 percent in Malta and 5.1 percent in Hungary. The latter was the second highest deficit in the European Union. However, the correlation is not deterministic. There were countries with favourable budget positions (Luxembourg and Germany) where the balance of the budget dropped by less than 5 percentage points, while Portugal and especially Greece - which had had substantial deficits in 2007 - were unable to avoid significant drops in their budget positions. We used this language on purpose, since the increase of the budget deficit can rise as a result of not only the conscious economy boosting fiscal measures but also because due to the crisis the revenues o the budget decrease 
Gyula Pulay, Jozsef Simon: The Resilient Adaptation of Budgets to Small...

significantly, while certain expenses of the budget (e.g. unemployment and social care services) increase substantially.

The figure also shows that in 2010 the majority of the countries tried to reduce their budget deficits which jumped during the years of the crisis, and apart from Portugal, only Luxembourg, Germany and the Netherlands - which had favourable budget situations in 2007 - allowed themselves to loosen the budget further in order to boost the economy. We do not include Ireland in this list because in Ireland the budget expenses increased primarily due to a very severe bank crisis.

All these point out that the central budget of a state can contribute to resilience in the national economy sense the best if the central budget is in a near-balanced condition during the soaring periods of the economic upturn, and therefore if it does not accumulate further government debt. This conclusion was drawn by the decision-makers of the European Union as well, since in 2011 they (except for the United Kingdom, Czech Republic and Croatia) signed the Treaty on Stability, Coordination and Governance in the Economic and Monetary Union, which is also known as the "fiscal compact". This is an intergovernmental agreement, the objective of which is to strengthen fiscal discipline, mainly in the countries of the euro area, but countries with national currencies could also join the contract. The treaty prescribes additional obligations compared to the criteria which have been valid since the Maastricht Treaty, namely

- the national budget deficit shall not exceed 3.0\% of the gross domestic product (GDP);

- the government debt-to-GDP ratio shall not exceed $60 \%$.

The objective set by the intergovernmental agreement is that the national budgets of the member states shall be balanced or have surplus under normal circumstances. In order to comply with this "balanced budget rule", the countries must keep their annual structural deficit on a level equal to $0.5 \%$ of the GDP or lower. (Structural deficit is the public finances deficit minus the effect of the economic cycle on government expenses and revenues.)

At the same time, the treaty already included the case where exceptional circumstances - for example severe economic downturn - occur. In that case the member states are granted temporary exemption from the balanced budget rules. (The compact contains several other rules as well, but those do not related directly to the subject of this article.) It follows from the above that these rules of the fiscal compact serve fiscal resilience in the broader sense, by establishing the legal (suspension of the balanced budget rules under exceptional circumstances) and financial (near-balanced budget balance) opportunity of the budget intervention.

At the same time, the member states can make use of this opportunity only if they actually keep their budget balances nearly balanced during periods of economic growth. It is reasonable to examine whether this objective of the budget treaty was achieved. The answer to this question can be deduced from Figure 6 .

The figure illustrates well that after the low points of the budget deficit in 2009 and 2010, the European average of the budget deficit-to-GDP ratio increased dramatically from 2012, and by 2019, the ratio was less than one percent. Consequently, the overall 
Figure 6: The development of the debt-to-GDP ratio of the government sector in the EU-28 (2008-2019)

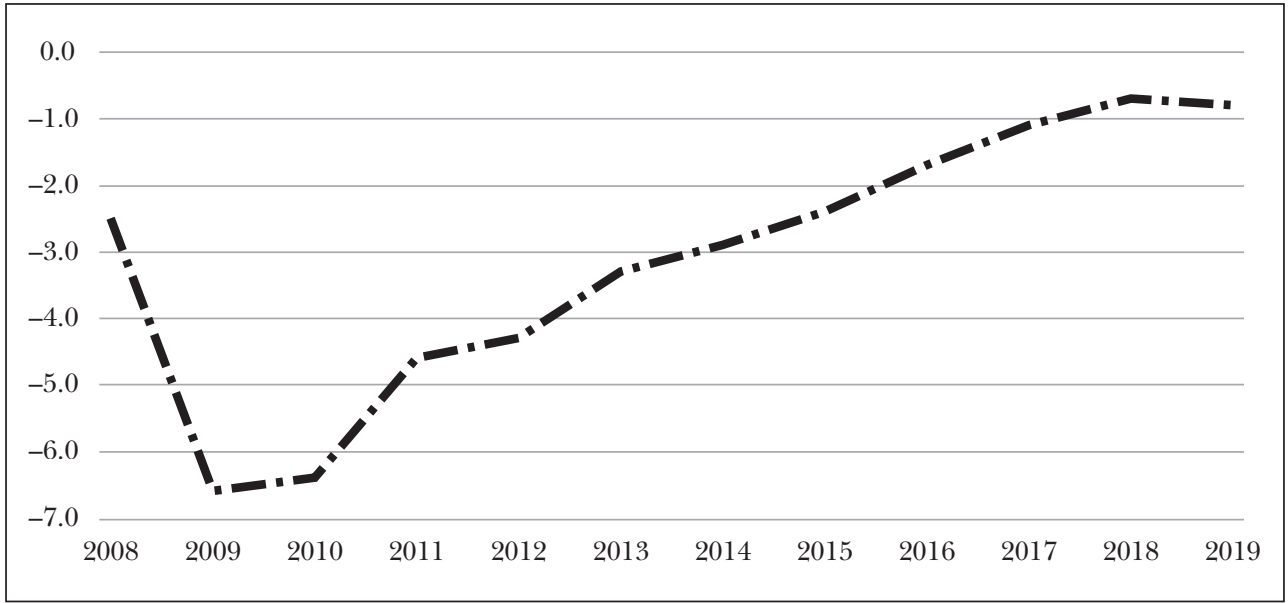

Source: Eurostat, https://ec.europa.eu/eurostat/databrowser/view/tec00127/default/line?lang=en

budget situation of the EU Member States was suitable for improving the resilience of the economies through increasing the budget expenses in this extraordinary situation. (Unfortunately, the same is not true for the budget positions of all Member States: the budget deficit-to-GDP ratio was 4.3 percent in Romania in 2019, 3.0 percent in France and 2.9 percent in Spain. At the same time, the budgets of 16 EU Member States were in surplus in 2019.) Consequently, the majority of the EU Member States had sufficient foundation for the fiscal overspending increasing the resilience of the economy.

The legal decision enabling the overspending was adopted very quickly as well. The Council of the European Union suspended the application of the budget rules already in March. The Council - which adopted the decision unanimously - is made up of the ministers of finance of the Member States, therefore there was a consensus that the requirement related to the budget deficit restrictions should be suspended in order to increase the resilience of the economy.

The fiscal decisions made in order to mitigate the shock caused by COVID-19 show that the EU Member State governments and the EU agencies had learned the lesson of the 2008-2009 crisis, namely, they switched from the narrower concept of fiscal flexibility - which is aimed at observing the budgetary rules - to the concept which aims at increasing the resilience of the entirety of the economy in time, and in the interest of this the governments gave up the effort to keep the budget deficit and the government debt under strict restrictions.

The concept of resilience itself was added to the dictionary of the management of the crisis caused by the epidemic. The key element of the recovery plan developed by the European Commission (hereinafter referred to as Commission) is called "Recovery and Resilience Facility". 
Gyula Pulay, Jozsef Simon: The Resilient Adaptation of Budgets to Small...

IS THE HUNGARIAN BUDGET RESILIENT IN CASE OF SHOCK-LIKE CHANGES?

It was already shown above that Hungary was one of the two countries where the budget deficit did not increase or increased only slightly during the 2008-2009 crisis. The background of this is explained by the data of Table 2 .

Table 2: The development of the most important indicators of the Hungarian budget and the development of the GDP (2005-2011)

\begin{tabular}{l|r|r|r|r|r|r|r}
\hline Name of indicator & $\mathbf{2 0 0 5}$ & $\mathbf{2 0 0 6}$ & $\mathbf{2 0 0 7}$ & $\mathbf{2 0 0 8}$ & $\mathbf{2 0 0 9}$ & $\mathbf{2 0 1 0}$ & $\mathbf{2 0 1 1}$ \\
\hline Balance of the government sector (GDP \%) & -7.7 & -9.2 & -5.0 & -3.7 & -4.7 & -4.4 & -5.2 \\
\hline Government debt-to-GDP ratio (GDP \%) & 60.0 & 64.1 & 65.0 & 71.8 & 78.2 & 80.6 & 80.8 \\
\hline Economic growth (\%) & 4.2 & 4.0 & 0.2 & 1.1 & -6.7 & 0.7 & 1.8 \\
\hline
\end{tabular}

Source: HCSO, www.ksh.hu/docs/hun/xstadat/xstadat_eves/i_qpt001.html; HCSO EDP notifications, www.ksh.hu/edp_notification

The table shows that in 2005 and 2006 - i.e. during the years of dynamic economic growth - the budget deficit was rather high and the government debt ratio increased. As a result, in 2009 the budget had only minimal room for manoeuvring left to take measures in order to increase the resilience of the economy. Indeed, although the deficit exceeded four percent of the GDP in 2009, but it was still lower than the deficit of 2007 and was higher than the 2008 deficit by merely 1 percentage point. Consequently, an increase in the deficit reflects the decrease of the revenues only, and not the increase of the economy boosting expenses. This too contributed to that Hungary became one of the countries where the global financial crisis caused the worst recession.

The Hungarian legislation reacted to this. Namely, the Fundamental Law of Hungary passed in 2011 stipulates the so-called government debt rule, according to which

- "The National Assembly may not adopt an Act on the central budget as a result of which the government debt would exceed half of the total gross domestic product.

- As long as the government debt exceeds half of the total gross domestic product, the National Assembly may only adopt an Act on the central budget which provides for a reduction of the ratio of government debt to the total gross domestic product."

At the time of the adoption of the Fundamental Law of Hungary the government debt exceeded 80 percent of the GDP, therefore the second rule had to be followed. This rule was realised in practice, and the ratio of the government debt between 2013 and 2019 to the total gross domestic product - the so-called government debt indicator - decreased continuously. In addition, the deficit of the government sector stayed below 3 percent of the GDP as well, however, it did not reach the nearbalanced state. 
Civic Review · Vol. 16, Special Issue, 2020

At the time of the eruption of the COVID-19 epidemic the Hungarian budget was in a much better shape than in 2008, which means that it had the financial conditions of the fiscal resilience in the broader sense. Are the legal conditions of fiscal resilience available? Yes, they are. The Fundamental Law stipulates basic provisions for the fiscal management of extraordinary situations. The Fundamental Law allows the National Assembly and the Government to deviate from the rules cited above during periods of special legal order, to the extent necessary to mitigate the circumstances inducing such legal order, or in case of the permanent and substantial downturn of the economy, to the extent necessary to restore the national economy balance.

The Fundamental Law of Hungary also has comprehensive rules applicable for states of danger. It stipulates that in the event of a natural disaster or industrial accident endangering the life and property, or in order to mitigate its consequences, the Government shall declare a state of danger, and may introduce extraordinary measures laid down in a cardinal Act. The cardinal Act stipulates that in case of state of danger provisions different from the rules applicable for public finances may be specified in decrees. The Government used this legislative authorisation and adopted several measures which support fiscal resilience in the broader sense: the Government ordered loan repayment moratorium, granted exemption from paying taxes and contributions in certain branches of the national economy for the months of March June 2020, and specified more flexible reserve use rules.

On the one hand, the measures of the Government are aimed at ensuring that sufficient funds are available for preventing and managing the epidemic. On the other hand, based on the fiscal and monetary decisions the goal is to ensure that enterprises and private persons keep as much funds as possible, in order to boost demand. The Government had been making decisions about the funding of investments steadily, which are considered to have anticyclical, economy boosting effect during the downturn caused by the crisis.

The state of danger ended on 18th June 2020, however, the state of danger had to be declared again due to the second wave of the epidemic in November. The decrease of the budget revenues and the increase in the expenses affects the entire 2020 budget. Consequently, the 2020 deficit of the government sector will be significantly higher than 3 percent of the GDP, and the government debt indicator will increase significantly.

Due to the prolonged and two-wave crisis, in 2021 the main task of the fiscal policy will be mitigating the negative consequences of the economic shock again. After the establishment of the resilience of the entirety of the economy, the narrower interpretation of fiscal policy will be in the forefront again. Compliance with the government debt rule is already set by the 2021 budget act as an objective. If the majority of the economy returns to the previous path of growth, then it would be reasonable for the budget to retreat back to the limits set previously again. 


\section{Gyula Pulay, József Simon: The Resilient Adaptation of Budgets to Small...}

\section{REFERENGES}

Domokos, L. (2019): Ellenốrzés - a fenntartható jó kormányzás eszköze [About the sustainable good governance]. Akadémiai Kiadó, Budapest.

European Commission (2020) Recovery plan for Europe. https://ec.europa.eu/info/live-work-travel-eu/ health/coronavirus-response/recovery-plan-europe_en.

Eurostat (2020): Government revenue, expenditure and main aggregates. https://appsso.eurostat. ec.europa.eu/nui/show.do?dataset=gov_10a_main\&lang=en.

Hungarian State Treasury (2017): A 2017. évi központi költségvetés végrehajtásának adatai [Data of the implementation of the 2017 central budget]. www.allamkincstar.gov.hu/hu/koltsegvetesi-informaciok/a2017-evi-kozponti-koltsegvetes-vegrehajtasanak-adatai

Hungarian State Treasury (2018): A 2018. évi központi költségvetés végrehajtásának adatai [Data of the implementation of the 2018 central budget]. www.allamkincstar.gov.hu/hu/koltsegvetesi-informaciok/2018evi-kozponti-koltsegvetes-vegrehajtasanak-adatai/.

IMF (2014): The Fiscal Transparency Code. International Monetary Fund, www.imf.org/external/np/fad/ trans/Code2019.pdf.

IMF (2018): Fiscal Transparency Handbook. International Monetary Fund, www.elibrary.imf.org/view/ IMF069/24788-9781484331859/24788-9781484331859/24788-9781484331859.xml?code=fth.

OECD (2015): Recommendation of the Council on Budgetary Governance. OECD, Public Governance and Territorial Development Directorate, www.oecd.org/gov/budgeting/Recommendation-of-the-Council-onBudgetary-Governance.pdf.

OECD (2017): Budgeting Transparency Toolkit. www.oecd.org/gov/budgeting/Budgeting-TransparencyToolkit.pdf.

Pulay, Gy. (2013): A költségvetési gazdálkodás és tervezés (költségvetési adótervezés) nemzetközi gyakorlata - OECD költségvetési alapelvei, az EU költségvetési irányelvei, az EU kis tagállamainak költségvetési gazdálkodási gyakorlata [International practices for fiscal management and planning (budgetary tax planning) - the budgeting principles of the OECD, the budgeting directives of the EU, fiscal management practice of the small Member States]. In: Lentner, Cs. (ed.): Közpénzügyek és államháztartástan II. [Public finances and government management II]. University of Public Service, Budapest.

Pulay, Gy.; Simon, J.; Kisapáti, A.; Tóth, L. and Mikes, B. (2019): Elemzés. A költségvetési elôirányzatok rugalmasabb tervezésének és végrehajtásának eszközei [Analysis. Possible means for the more flexible planning and implementation of budget appropriations]. State Audit Office of Hungary, Budapest, www.asz.hu/ storage/files/files/elemzesek/2019/rte_20190313.pdf?ctid=1271. 